\title{
USE OF PATHOGENICITY AND ELECTROPHORETIC PROTEIN AND ALCHOL DEHYDROGENASE PATTERNS TO DIFFERENTIATE AMONG ISOLATES WITHIN Fusarium SPECIES
}

\author{
El-Samawaty, A.M.A.; M.T.M. Mansour; M.R. Omar and
} Amal A. Asran

Plant Pathology Research Institute, Agric. Res. Center, Giza, Egypt.

\begin{abstract}
Twenty isolates belonging to nine Fusarium spp. were tested for levels of pathogenicity on two cotton cultivars under greenhouse conditions. Preemergence damping-off, postemergence damping-off, survival and dry weight were used as criteria to evaluate pathogenicity of the isolates. Proteins and alcohol dehydrogenase (AD) isozymes of the isolates were separated by SDS-PAGE, and PAGE, respectively. Virulence patterns, protein banding patterns, and AD isozymic patterns patterns were used to differentiate among Fusarium isolates belonging to the same species. In the three methods, cluster analysis was used to differentiate among the isolates, which showed low similarity levels-that is, the isolates, which belonged to remotely related or unrelated subclusters. On the other hand, cluster analysis was not a reliable method to differentiate among the isolates belonging to closely related subclusters because such isolates had relatively high similarity levels. The results of the present study suggest that isolates belonging to the same Fusarium species could be differentiated by their differential pathogenicity, combined with their specific protein and AD banding patterns separated by electrophoresis.
\end{abstract}

Keywords: Fusarium, cotton, pathogenicity, electrophoresis, proteins, isozymes.

\section{INTRODUCTION}

Species of Fusarium have been associated with cotton seedling disease and are major cause of seedling death in some countries involving Egypt (Watkins, 1981; Minton and Garber, 1983; Aly et al., 1996, and El-Samawaty, 2004). Fusarium oxysporum, F. solani and F. moniliforme are commonly isolated from cotton seedlings infected with damping-off in Egypt (Jakob, 1969; Aly et al., 1998; El-Samawaty, 1999, and Abd-El-Salam, 2006). F. tabacinum, F. sambucinum, F. avenaceum, F. poae, F. fusarioides, $F$. subglutinans, and $F$. sporotrichioides were recorded as new pathogens to seedling of the Egyptian cotton (El-Samawaty, 1999 and 2004).

Electrophoresis of proteins has been widely used for studying variation among isolates within Fusarium species. For example, Lo and Sun (1986) found that protein pattern in vertical slab electrophoresis of $F$. oxysporum from radish different from that of $F$. oxysporum from mustard and $F$. oxysporum from Kale. Lodwing et al. (1999) used electrophoretic prpfiles of total proteins to distinguish isolates 27 and 30 of $F$. oxysporum f.sp. cubense and F. oxysporum from Triticum sp. Aly et al. (2000) reported that electrophoretic banding patterns of dissociated proteins separated four Egyptian races of $F$. oxysporum f.sp. ciceris. 
Isozymes (isoenzymes) are defined as genetically determined multiple molecular forms of an enzyme. There are three main causes of formation of multiple molecular forms of enzymes. These are (1) the presence of more than one gene locus coding for the enzyme, (2) the presence of more than one allele at a single gene locus coding for the enzyme, and (3) the post translation modifications of the formed enzymatic polypeptide resulting in formation of nongenetic or so-called "secondary" isozymes. The term isozymes is usually used to denote multiple molecular forms deriving from different genetic loci, where the term "allozymes" is used to denote multiple molecular forms deriving from different alleles of the sane genetic locus. The term "allelic isozymes" is also used by isozymologists (Manchenko, 1994). Isozymes have similar, if not identical enzymatic properties but slightly different amino acid sequences. Only those isozymes with amino acid compositions of different net charge, or those that result in large differences in the shape of an enzyme, can be differentiated by electrophoresis (Bonde et al., 1993).

Isozymes analysis is a powerful biochemical technique that has numerous applications in plant pathology. It was being used routeinly to settle taxonomic disputes, identify cultures "fingerprint" patentable fungal lines, analysis genetic variability, trace pathogen spread, follow the segregation of genetic loci, and identify ploidy levels of fungi and other plant pathogens (Bonde et al., 1993; Some and Tivoli, 1993 and YliMattila et al., 1995).

The objectives of this investigation were to differentiate among isolates within Fusarium species by using virulence patterns, protein banding patterns, and isozymic patterns of alcohol dehydrogenase.

\section{MATERIALS AND METHODS}

\section{Isolates of Fusarium spp.}

Isolates of Fusarium spp. used in this study were obtained from roots of cotton seedlings infected with damping-off disease. Isolation, purification, and identification of these isolates were carried out at Cotton Pathology Res. Dept., Plant Pathology Res. Inst., Agric. Res. Center, Giza, Egypt.

\section{Pathogenicity test of Fusarium spp. on cotton cultivars}

Substrate for growth of each isolate was prepared in $500 \mathrm{ml}$ glass bottles; each bottle contained $50 \mathrm{~g}$ of sorghum grains and $40 \mathrm{ml}$ of tap water. Contents of bottles were autoclaved for $30 \mathrm{~min}$. Isolate inoculum, taken from one-week old culture on PDA, was aseptically introduced into the bottle and allowed to colonize sorghum for 3 weeks. The present test was carried out by using autoclaved clay loam soil. Batches of soil were infested separately with inoculum of each isolate at a rate of $50 \mathrm{~g} / \mathrm{kg}$ of soil. Infested soil was dispensed in $-10-\mathrm{cm}$ diameter clay pots and these were planted with seeds (10 seeds/pot) of tow cotton cultivars (Giza 80, and Giza 90). In control treatment, sterilized sorghum grains were mixed thoroughly with soil at the 
rate of $50 \mathrm{~g} / \mathrm{kg}$ of soil. Pots were randomly distributed on greenhouse benches. Prevailing temperatures during pathogenicity tests were $24 \pm 3^{\circ} \mathrm{C}$ to $33 \pm 2.5^{\circ} \mathrm{C}$. Percentage of pre-emergence damping-off was recorded 15 days after planting. Post-emergence damping-off, survival and dry weight (mg/plant) were recorded 45 days after planting.

\section{Statistical analysis of data}

The experimental design of pathogenicity test was a randomized complete block with four replicates. Analysis of variance (ANOVA) of the data was performed with the MSTAT-C statistical package (A Micro-Computer Program for the Design, Management, and Analysis of Agronomic Research Experiments, Michigan State Univ., USA). Least significant difference (LSD) was used to compare isolate means within cultivars. Percentage data were transformed into arc sine angles before carrying out the ANOVA, to produce approximately constant variance.

\section{Extraction of fungal proteins}

Protein extracts from Fusarium spp. isolates were prepared according to Hussein (1992) in the following way: Fungal isolates were grown for 22 days at $22-30^{\circ} \mathrm{C}$ on liquid Czapek medium. The mycelium was harvested by filtration through cheesecloth, washed with distilled water several times, and freeze-dried. This frozen mycelium was suspended in phosphate buffer $\mathrm{pH}$ 8.3 (1-3 ml/g mycelium), mixed thoroughly with glass beads, and ground in liquid nitrogen to a fine powder. The ground mycelium was centrifuged at $19,000 \mathrm{rpm}$ for 30 minutes at $0^{\circ} \mathrm{C}$. The protein content in the supernatant was estimated according to Bradford (1976) by using bovine serum albumin as a standard protein. If protein concentration was low, protein was precipitated from the clarified supernatant by adding ammonium sulphate at $70 \%$ of saturation $(60 \mathrm{~g} / 100 \mathrm{ml})$ then kept in the refrigerator for $30 \mathrm{hr}$. Pellets, collected by centrifugation at $11,000 \mathrm{rpm}$ for 30 minutes, were resuspended in phosphate buffer $\mathrm{pH} 8.3$ and subjected to dialysis for $24 \mathrm{hr}$ against the buffer and centrifugation at $11,000 \mathrm{rpm}$ for 30 minutes. Protein was estimated in the obtained supernatant.

\section{Electrophoresis of dissociated protein (SDS-PAGE)}

Each supernatant was mixed with an equal volume of a solution consisting of (by volume) $64 \%$ buffer $(0.15 \mathrm{M}$ Tris $\mathrm{HCl}, \mathrm{pH} 6.8), 20 \%$ glycerol, $6 \%$ SDS, $10 \%$ 2-6-mercaptoethanol, and $0.1 \%$ bromophenol blue, before boiling in a water bath for three minutes. Twenty-microliters samples $(40 \mu \mathrm{g}$ of protein) were subjected to electrophoresis in a $7.5 \%$ polycarylamid gel prepared $0.1 \%$ SDS with a $3.5 \%$ stacking gel (Laemmli, 1970). Electrophoresis was conducted at $10^{\circ} \mathrm{C}$ for $4 \mathrm{hr}$ at 15 and $30 \mathrm{~mA}$ for the stacking and the separating gels, respectively, until dye reached the bottom of the separating gel. Electrophoresis was performed in vertical slab mold $(16 \times 18 \times 0.15 \mathrm{~cm})$. Gels were stained with silver nitrate for the detection of protein bands (Sammons et al., 1981). 


\section{Electrophoresis of isozymes}

Protein-extract supernatant was mixed with an equal volume of a solution containing $20 \%$ glycerol (vol $/ \mathrm{vol}$ ) and 0.1 bromophenol blue (vol $/ \mathrm{vol})$ in 0.15 $\mathrm{M}$ Tris- $\mathrm{HCl}, \mathrm{pH}$ 6.8. Twenty microliters of the resulting suspension (40 to 60 $\mu \mathrm{g}$ of protein) was subjected to electrophoresis in $25 \mathrm{mM}$ Tris buffer containing $192 \mathrm{mM}$ glycin at $\mathrm{pH}$ 8.3. Electrophoresis was conducted at $10^{\circ} \mathrm{C}$ for $4 \mathrm{hr}$ on a $7.5 \%$ polyacrylamide gel with a $3.5 \%$ stacking gel, at 30 and 15 $\mathrm{mA}$, respectively, until the dye reached the bottom of the separating gel (Laemmli, 1970). Electrophoresis was performed in a vertical slab mold $(16 \times 18 \times 0.15 \mathrm{~cm})$. Gels were stained according to Manchenko (1994) for the detection of isozymes of alcohol dehydrogenase.

\section{Gel analysis}

A gel documentation system (Advanced American Biotechnology 1166 E. Valencia Dr. Unit 6C, Fullerton CA 92631) was used to document the results of PAGE and to cluster the electrophoretic patterns by the unweighted pair-group method based on arithmetic mean (UPGMA).

\section{RESULTS AND DISCUSSION}

ANOVA (Table 1) showed that isolate, cultivar, and isolate $X$ cultivar interaction were very high significant sources of variation in all the tested parameters except the cultivar, which was a nonsignificant source of variation in pre-emergence damping-off.

Isolate was the first in importance as a source of variation in all tested parameters, while isolate $X$ cultivar interaction was the second in importance, and cultivar was the least importance source of variation in all the tested parameters (Table 2).

Due to the significance of isolates $\mathrm{x}$ cultivar interaction, LSD was calculated to compare means of isolates within each cultivar. This comparison showed that the differences between isolates and the control were not the same for each cultivar. Similarly, the differences among isolates differ from one cultivar to another e.g. Isolates of both $F$. solani 3 and $F$. oxysporum 8 were pathogenic on Giza 80 and non pathogenic on Giza 90. The differences between $F$. sporotrichioides isolates 10 and11 was significant on cultivar Giza 80, while it was nonsignificant on cultivar Giza 90. Also the difference between $F$. sambucinum isolates 14 and 15 was significant on cultivar Giza 90 and non significant on Giza 80 (Table 3). The same conclusion held true for the data of post-emergence damping-off, survival, and dry weight (Tables 4,5 , and 6). The results in this study suggest that isolates of Fusarium spp. exhibited diversity in pathogenicity on cotton cultivars. This result is in agreement with that of Batson \& Borazjani (1984), Aly et al. (1996), El-Samawaty (1999), and Abd-Elsalam (2007). 
Table 1. Analysis of variance of effect of Fusarium isolate, cotton cultivar and their interaction on seedling diseases parameters under greenhouse conditions.

\begin{tabular}{|c|c|c|c|c|}
\hline Parameter and source of variation* & D.F & M.S & F. Value & $\mathrm{P}>\mathrm{F}$ \\
\hline \multicolumn{5}{|l|}{ Preemergence damping-off } \\
\hline Replication & 3 & 117.949 & 2.306 & 0.080 \\
\hline Isolate (I) & 20 & 568.950 & 11.123 & 0.000 \\
\hline Cultivar (C) & 1 & 33.760 & 0.660 & \\
\hline IXC & 20 & 272.149 & 5.320 & 0.000 \\
\hline Error & 123 & 51.152 & & \\
\hline \multicolumn{5}{|l|}{ Postemergence damping-off } \\
\hline Replication & 3 & 92.029 & 1.815 & 0.148 \\
\hline Isolate (I) & 20 & 701.703 & 13.841 & 0.000 \\
\hline Cultivar (C) & 1 & 467.167 & 9.215 & 0.003 \\
\hline IXC & 20 & 342.244 & 6.750 & 0.000 \\
\hline Error & 123 & 50.699 & & \\
\hline \multicolumn{5}{|l|}{ Survival } \\
\hline Replication & 3 & 196.943 & 1.171 & 0.324 \\
\hline Isolate (I) & 20 & 1618.970 & 9.624 & 0.000 \\
\hline Cultivar (C) & 1 & 1325.084 & 7.877 & 0.006 \\
\hline IXC & 20 & 531.786 & 3.161 & 0.000 \\
\hline Error & 123 & 168.214 & & \\
\hline \multicolumn{5}{|l|}{ Dry weight } \\
\hline Replication & 3 & 25117.609 & 1.624 & 0.187 \\
\hline Isolate (I) & 20 & 171139.518 & 11.068 & 0.000 \\
\hline Cultivar (C) & 1 & 211225.292 & 13.661 & 0.000 \\
\hline IXC & 20 & 27124.679 & 1.754 & 0.033 \\
\hline Error & 123 & 15461.918 & & \\
\hline
\end{tabular}

${ }^{*}$ Replication is random, while each of isolate and cultivar is fixed.

Table 2. Relative Contribution of cotton cultivar, Fusarium spp. isolate, and their interaction to variation in seedling diseases parameters:

\begin{tabular}{|c|c|c|c|c|}
\hline \multirow[b]{2}{*}{$\begin{array}{l}\text { Source } \\
\text { Variation }\end{array}$} & \multicolumn{4}{|c|}{$\begin{array}{ll}\text { Relative contribution }{ }^{\mathrm{a}} \text { to variation in } \\
\end{array}$} \\
\hline & $\begin{array}{c}\text { Preemregence } \\
\text { Damping-off }\end{array}$ & $\begin{array}{l}\text { Postemergence } \\
\text { Damping-off }\end{array}$ & Survival & Dry weight \\
\hline Isolate & 66.12 & 64.91 & 72.07 & 80.50 \\
\hline Cultivar & 0.20 & 2.16 & 2.95 & 4.97 \\
\hline IXC & 31.63 & 31.66 & 23.67 & 12.76 \\
\hline
\end{tabular}

a Calculated as percentage of sum squares of the explained (model) variation.

In the present study, virulence patterns, protein banding patterns, and isozymic patterns of 20 isolates of Fusarium spp. were used, basically, to differentiate among Fusarium isolates belonging to the same species. In the three methods, cluster analysis was used to differentiate among the isolates, which showed low similarity levels- that is, the isolates, which belonged to remotely related or unrelated subclusters. On the other hand, cluster analysis was not a reliable method to differentiate among the isolates belonging to closely related subclusters because such isolates had relatively high similarity levels. 
El-Samawaty, A.M.A. et al.

The phenogram of Fig. (1) was constructed based on pathogenicity test shown in Tables (3-6).

Table 3. Effect of cotton cultivar, Fusarium isolate, and their interaction on preemergence damping-off of cotton seedlings under greenhouse conditions.

\begin{tabular}{|c|c|c|c|c|c|c|}
\hline \multirow{3}{*}{ Fungus isolates } & \multicolumn{6}{|c|}{ Cultivar } \\
\hline & \multicolumn{2}{|c|}{ Giza 80} & \multicolumn{2}{|c|}{ Giza 90} & \multicolumn{2}{|c|}{ Mean } \\
\hline & $\%$ & Trans & $\%$ & Trans & $\%$ & Trans \\
\hline $1-F$. solani & 35 & 36.22 & 15 & 22.50 & 25 & 29.36 \\
\hline 2-F. solani & 15 & 22.50 & 35 & 36.00 & 25 & 29.25 \\
\hline 3-F. solani & 55 & 47.88 & 25 & 29.36 & 40 & 38.62 \\
\hline 4-F. moniliforme & 50 & 45.00 & 42.5 & 40.61 & 46.25 & 42.81 \\
\hline 5- $F$. moniliforme & 37.5 & 37.44 & 27.5 & 31.02 & 32.5 & 34.23 \\
\hline 6-F. moniliforme & 30 & 33.05 & 60 & 52.56 & 45 & 42.81 \\
\hline 7-F. oxysporum & 55 & 47.88 & 50 & 45.00 & 52.5 & 46.44 \\
\hline 8-F. oxysporum & 30 & 33.05 & 20 & 28.22 & 25 & 30.64 \\
\hline 9-F. oxysporum & 37.5 & 37.72 & 27.5 & 31.02 & 32.5 & 34.37 \\
\hline 10-F. sporotrichioides & 65 & 54.06 & 45 & 42.05 & 55 & 48.06 \\
\hline 11-F. sporotrichioides & 40 & 39.17 & 40 & 39.10 & 40 & 39.14 \\
\hline 12-F. subglutinans & 17.5 & 24.53 & 30 & 32.53 & 23.75 & 28.53 \\
\hline 13-F. sambucinum & 45 & 42.11 & 22.5 & 28.22 & 33.75 & 35.17 \\
\hline 14-F. sambucinum & 30 & 33.05 & 42.5 & 40.39 & 36.25 & 36.72 \\
\hline $15-F$. sambucinum & 45 & 42.05 & 85 & 70.45 & 65 & 56.25 \\
\hline 16-F.poae & 40 & 39.17 & 47.5 & 43.56 & 43.75 & 41.36 \\
\hline 17-F. poae & 55 & 47.88 & 57.5 & 49.39 & 56.25 & 48.64 \\
\hline 18-F. semitectum & 37.5 & 37.50 & 22.5 & 28.22 & 30 & 32.86 \\
\hline 19-F. semitectum & 30 & 33.05 & 17.5 & 21.58 & 23.75 & 27.32 \\
\hline 20-F. fusarioides & 40 & 38.95 & 40 & 39.40 & 40 & 39.03 \\
\hline Control & 15 & 19.92 & 15 & 22.50 & 15 & 21.21 \\
\hline Mean & 38.3 & 37.72 & 36.6 & 36.83 & & \\
\hline
\end{tabular}

Trans: \% data were transformed into arc sine angles before the analysis of variance.

LSD (transformed data) for cultivar $X$ isolates interaction $=10.01(P<0.05)$ or $13.23(P<$ 0.01).

Isolates of $F$. sambucinum nos. 13,14 , and 15 were easily distinguished based on their virulence patterns (Fig. 1), which placed the isolates in three remotely related subclusters. It was not possible to differentiate between $F$. solani isolates nos. 1 and 3 , while it was easy to differentiate between any of the two isolates and $F$. solani no. 2, which belonged to remotely related subcluster. Within $F$. oxysporum and $F$. moniliforme, it was difficult to differentiate among isolates.

Amino acid sequence of polypeptides (components of proteins and isozymes) are dependent on nucleotide sequence of their coding genes; therefore, an analysis of protein and isozymic variation among Fusariumi isolates within species by electrophoresis, approximates on analysis of their genetic variation (Markert and Faulhaber, 1965). The phenogram shown in Fig. 3 was constructed based on cluster analysis of protein banding patterns of the tested isolates (Fig. 2). 
J. Agric. Sci. Mansoura Univ., 33(5), May, 2008

F1

3433 
El-Samawaty, A.M.A. et al.

f2 
J. Agric. Sci. Mansoura Univ., 33(5), May, 2008

F3

3435 
In this phenogram, it was difficult to differentiate between isolates nos. 7 and 8 of $F$. oxysporum due to their high similarity level; however, it was possible, to some extent, to differentiate between any of them and isolate no. 9. It was difficult to differentiate between isolates nos. 4 and 5 of $F$. moniliforme based on their protein profiles; however, these profiles distinguish each of them from isolate no. 6 of $F$. moniliforme. The same conclusion held true for isolates nos. 1 and 2 of $F$. solani and isolate no. 3. Protein profiles were highly successful in differentiating between isolate no. 14 of $F$. samucinum and each of isolates nos. 13 and 15 of the same fungus. Similarly, isolates nos. 19 and 18 of $F$. semitectum were easily distinguished by their protein profiles.

Electrophoresis patterns of isozymes can be obtained rapidly and the growing conditions have no influence on these patterns (Koberhel and Gautier, 1974). Fig. 5 showed a phenogram based on cluster analysis of alcohol dehydrogenase (AD) isozymes (Fig. 4).

Table 4. Effect of cotton cultivar, Fusarium isolate, and their interaction on postemergence damping-off of cotton seedlings under greenhouse conditions.

\begin{tabular}{|c|c|c|c|c|c|c|}
\hline \multirow{3}{*}{ Fungus Isolates } & \multicolumn{6}{|c|}{ Cultivar } \\
\hline & \multicolumn{2}{|c|}{ Giza 80} & \multicolumn{2}{|c|}{ Giza 90} & \multicolumn{2}{|c|}{ Mean } \\
\hline & $\%$ & Trans & $\%$ & Trans & $\%$ & Trans \\
\hline $1-F$. solani & 65 & 53.78 & 37.5 & 37.44 & 51.25 & 45.61 \\
\hline 2-F. solani & 17.5 & 24.53 & 30 & 32.31 & 23.75 & 28.42 \\
\hline 3-F. solani & 37.5 & 37.51 & 57.5 & 49.39 & 47.50 & 43.45 \\
\hline 4-F. moniliforme & 35 & 36.22 & 35 & 26.22 & 35.00 & 36.22 \\
\hline 5- $F$. moniliforme & 12.5 & 20.47 & 35 & 36.22 & 47.50 & 28.34 \\
\hline 6-F. moniliforme & 65 & 53.78 & 32.5 & 34.56 & 48.75 & 44.17 \\
\hline 7-F. oxysporum & 30 & 32.90 & 37.5 & 37.66 & 33.75 & 35.28 \\
\hline 8-F. oxysporum & 60 & 50.83 & 15 & 22.50 & 37.50 & 36.67 \\
\hline 9-F. oxysporum & 35 & 36.22 & 45 & 42.05 & 40.00 & 39.14 \\
\hline 10-F. sporotrichioides & 22.5 & 27.85 & 17.5 & 24.53 & 20.00 & 26.19 \\
\hline 11-F. sporotrichioides & 55 & 47.89 & 40 & 39.10 & 47.50 & 43.49 \\
\hline 12-F. subglutinans & 35 & 35.47 & 42.5 & 40.61 & 38.75 & 38.04 \\
\hline 13-F. sambucinum & 45 & 42.11 & 57.5 & 49.39 & 51.25 & 45.75 \\
\hline 14-F. sambucinum & 57.5 & 49.39 & 42.5 & 40.61 & 50.55 & 45.00 \\
\hline $15-F$. sambucinum & 42.5 & 40.61 & 15 & 19.55 & 28.75 & 30.08 \\
\hline 16-F. poae & 42.5 & 40.61 & 27.5 & 31.39 & 35.00 & 36.00 \\
\hline 17-F. poae & 35 & 36.22 & 32.5 & 34.56 & 33.75 & 35.39 \\
\hline $18-F$. semitectum & 37.5 & 37.66 & 60 & 50.90 & 48.75 & 44.28 \\
\hline $19-F$. semitectum & 30 & 33.05 & 40 & 39.16 & 35.00 & 36.11 \\
\hline 20-F. fusarioides & 37.5 & 37.72 & 7.5 & 11.25 & 22.50 & 24.49 \\
\hline Control & 5 & 9.22 & 2.5 & 4.61 & 3.75 & 6.91 \\
\hline Mean & 38.21 & 37.34 & 33.81 & 34.00 & & \\
\hline
\end{tabular}


J. Agric. Sci. Mansoura Univ., 33(5), May, 2008 F4 
EI-Samawaty, A.M.A. et al.

F5 
It was clear that the intraspecific differentiatiability of $A D$ isozymes was much better than that of protein profiles due to low similarity levels among isolates based on $A D$ isozymes. Thus it was easy to differentiate among isolates within species. For example, the two isolates of $F$. semitectum nos. 18 and 19 , the two isolates of $F$. sporotrichoides nos. 10 and 11, and the three isolates of $F$. samucinum. Isolates nos. 7 of $F$. oxysporum, no. 6 of $F$. moniliforme, and no. 1 of $F$. solani were easily distinguished from the other isolates belonging to the same species.

Therefore, it seems reasonable to conclude that the observed isolate specific protein and isozymic patterns may be useful as biochemical markers in ecological studies in soil where "marked" isolates are needed. The virulence patterns of Fusarium isolates combined with their protein and isozymic patterns would facilitate their identification after reisolation from soil.

Table 5. Effect of cotton cultivar, Fusarium isolate, and their interaction on survival of cotton seedlings under green house conditions.

\begin{tabular}{|c|c|c|c|c|c|c|}
\hline \multirow{3}{*}{ Fungus Isolates } & \multicolumn{6}{|c|}{ Cultivar } \\
\hline & \multicolumn{2}{|c|}{ Giza 80} & \multicolumn{2}{|c|}{ Giza 90} & \multicolumn{2}{|c|}{ Mean } \\
\hline & $\%$ & Trans & $\%$ & Trans & $\%$ & $\overline{\text { Trans }}$ \\
\hline 1-F. solani & 0.00 & 0.00 & 47.50 & 43.56 & 23.75 & 21.78 \\
\hline 2-F. solani & 67.50 & 55.44 & 35.00 & 34.60 & 51.25 & 45.02 \\
\hline 3-F. solani & 7.50 & 8.30 & 17.50 & 17.89 & 46.25 & 13.10 \\
\hline 4-F. moniliforme & 15.00 & 19.55 & 22.50 & 28.22 & 18.75 & 23.89 \\
\hline 5-F. moniliforme & 50.00 & 45.00 & 37.50 & 37.44 & 43.75 & 41.22 \\
\hline 6- $F$. moniliforme & 5.00 & 6.64 & 5.00 & 9.22 & 5.00 & 7.93 \\
\hline 7-F. oxysporum & 15.00 & 16.60 & 12.50 & 14.94 & 13.75 & 15.77 \\
\hline 8-F. oxysporum & 10.00 & 13.28 & 62.50 & 52.34 & 36.25 & 32.81 \\
\hline 9-F. oxysporum & 27.50 & 31.55 & 27.50 & 27.68 & 27.50 & 29.62 \\
\hline 10-F. sporotrichioides & 12.50 & 11.25 & 37.50 & 37.50 & 25.00 & 24.38 \\
\hline 11-F. sporotrichioides & 5.00 & 9.22 & 20.00 & 26.56 & 12.50 & 17.89 \\
\hline 12-F. subglutinans & 47.50 & 43.56 & 30.00 & 32.31 & 38.75 & 37.93 \\
\hline 13-F. sambucinum & 10.00 & 18.44 & 20.00 & 25.08 & 15.00 & 21.76 \\
\hline 14-F. sambucinum & 12.50 & 11.25 & 15.00 & 15.86 & 13.75 & 13.56 \\
\hline 15-F. sambucinum & 12.50 & 14.42 & 0.00 & 0.00 & 6.25 & 7.21 \\
\hline 16-F. poae & 17.50 & 21.58 & 25.00 & 29.73 & 21.25 & 25.65 \\
\hline 17-F. poae & 10.00 & 15.86 & 10.00 & 12.91 & 10.00 & 14.39 \\
\hline 18-F. semitectum & 25.00 & 29.14 & 17.50 & 23.64 & 21.25 & 26.39 \\
\hline 19-F. semitectum & 40.00 & 39.10 & 42.50 & 40.55 & 41.25 & 39.83 \\
\hline 20-F. fusarioides & 22.50 & 27.11 & 52.50 & 46.50 & 37.50 & 36.81 \\
\hline Control & 80.00 & 66.75 & 85.00 & 65.45 & 82.50 & 66.10 \\
\hline Mean & 26.67 & 24.00 & 29.64 & 29.62 & & \\
\hline
\end{tabular}


El-Samawaty, A.M.A. et al.

Table 6. Effect of cotton cultivar, Fusarium isolate, and their interaction on dry weight ( $\mathrm{mg} /$ plant) of cotton seedlings under green house conditions.

\begin{tabular}{lccc}
\hline Fungus Isolates & \multicolumn{3}{c}{ Cultivar } \\
\cline { 2 - 4 } & Giza $\mathbf{8 0}$ & Giza 90 & Mean \\
\hline $1-$ F. solani & 389.0 & 477.3 & 433.1 \\
2-F. solani & 208.8 & 346.0 & 277.4 \\
3-F. solani & 238.5 & 255.0 & 246.8 \\
4-F. moniliforme & 95.75 & 131.8 & 113.8 \\
5-F. moniliforme & 241.5 & 212.0 & 226.8 \\
6-F. moniliforme & 171.5 & 197.3 & 184.4 \\
7-F. oxysporum & 195.8 & 190.5 & 193.1 \\
8-F. oxysporum & 216.3 & 354.8 & 285.5 \\
9-F. oxysporum & 177.0 & 183.8 & 180.4 \\
10-F. sporotrichioides & 496.3 & 434.0 & 465.1 \\
11-F. sporotrichioides & 95.0 & 231.3 & 163.1 \\
12-F. subglutinans & 136.0 & 0.00 & 68.0 \\
13-F. sambucinum & 438.5 & 424.3 & 431.4 \\
14-F. sambucinum & 226.3 & 391.5 & 308.9 \\
15-F. sambucinum & 97.0 & 450.5 & 273.8 \\
16-F. poae & 101.5 & 287.5 & 194.5 \\
17-F. poae & 0.00 & 248.0 & 124.0 \\
18-F. semitectum & 363.5 & 290.8 & 327.1 \\
19-F. semitectum & 57.50 & 177.3 & 117.4 \\
20-F. fusarioides & 318.3 & 454.3 & 386.3 \\
Control & 672.0 & 687.5 & 679.8 \\
\hline Mean & 235.0 & 306.0 & \\
\hline
\end{tabular}

LSD for cultivar $X$ isolates interaction $=174(P<0.05)$ or $230(P<0.01)$.

\section{REFERENCES}

Abd-Elsalam, K.A.; Amal Abdel-Mongy A., M.R. Omar, and A.A. Aly. 2006. frequency and diversity of Fusarium spp. colonizing roots of Egyptian cottons. Arch. Phytopathol. and Plant Protec. 39(3): 165-177.

Abd-Elsalam, K.A.; M.R. Omar, A.M. El-Samawaty, and A.A. Aly. 2007. Response of commercial cotton cultivar to Fusarium Solani. Plant Pathol. J. 23(2):62-69.

Aly, A.A.; E.M. Hussein, M.A. Mostafa, and A.I. Ismail. 1996. Distribution, identification, and pathogenicity of Fusarium spp. isolated from some Egyptian cottons. Menofiya J. Agric. Res. 21: 819-836.

Ali, A.A., S.A. Omar, and M.R. Omar. 2000. Separation of four races of Fusarium oxysporum f.sp. ciceris by protein electrophoresis. Minufiya J. Agric. Res. 25:13-20.

Baston, W.E., and A. Borazjani. 1984. Effect of selected isolates of four species of Fusarium on establishment and early growth of cotton. Phytopathology 74: 625 (Abst.)

Bonde, M.R., J.A. Micales, and G.L. Peterson. 1993. The use of isozyme analysis for identification of plant-pathogenic fungi. Plant Disease 77: 961-968. 
Bradford, M.M. 1976. A rapid and sensitive method for the quantification of microgram quantities of protein utilizing the principle of protein-dye binding. Anal. Biochem 72: 248-254.

El-Samawaty, A.M.A. 1999. Studies on cotton root rot disease. Ms Thesis. Assiut Univ. Assiut, Egypt. 105 pp.

El-Samawaty, A.M.A. 2004. Pathological studies on the interaction between some Fusarium spp. and cotton plants. Ph.D. Thesis Minia Univ. Minia, Egypt. 117 pp.

Hussein, E.M. 1992. Biochemical and serological studies for determining susceptibility of cotton cultivars to Fusarium oxysporum f.sp. vasinfectum (in Russian). Ph.D. Thesis. All-Union Institute of Plant Protection. Leningrad, USSR.

Jakob, H.M. 1969. Fungal diseases of cotton seedling in Egypt. Pflanzenschuz-nachr. 22:244-286.

Koberhel, A.S. and A.H. Gautier. 1974. Peroxidase isozymes from horseradish roots. J. Biol. Chem. 242:1470-2473.

Laemmli, U.K. 1970. Cleavage of structural proteins during the assembly of the head of bacteriophage T4. Nature 227: 680-685.

Lodwing, E.M., P.D. Bridge, M.A. Rutherford, U.K. Kung, and P. Jeffries. 1999. Molecular differences distinguish clonal lineages within east Africa populations of Fusarium oxysporum F.sp. cubense. J. Appl. Microbiol. 86:71-77.

Lo, C.T. and S.K. Sun. 1986. Characterization of Fusarium oxysporum isolated from cruciferous vegetable in Taiwan. Plant Protec. Bull., Taiwan 28:213-223.

Manchenko, G.P. 1994. "Handbook of Detection of Enzymes on Electrophoretic Gels". CRC Press, Inc., Boca Raton, Florida, 341 p.

Markert, C.L. and I. Faulhaber. 1965. Lactate dehydrogenase isozyme patterns of fish. J. Exp. Zool. 159: 319-332.

Minton, E.B., and R.H. Garber. 1983. Controlling the seedling disease complex of cotton. Plant Dis. 67: 115-118.

Sammons, D.W., L.D. Adams, and E.E. Nishizawa. 1981. Ultra-sensitive silver based color staining of polypeptides in polyacrylamide gels. Electrophoresis 2:135.

Some, A. and B. Tivoli. 1993. Fusarium spp. from potato: polymorphism of esterase phenotypes on polyacrylamide gel electrophoresis. Agronomie 13:637-649.

Watkins, G.M. 1981. Compendium of Cotton Diseases. The American Phytopathological Society, St. Paul., Minnesota, 87p.

Yli-Mattila, T., S. Paavanen, A. Hannukala, P. Parikka, and R. Tahvonen. 1995. Identification of Fusarium avenaceum strains by isozyme analysis. Bull. OEPP 25:89-93. 


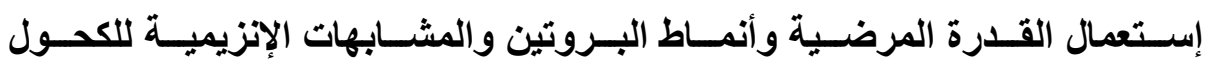

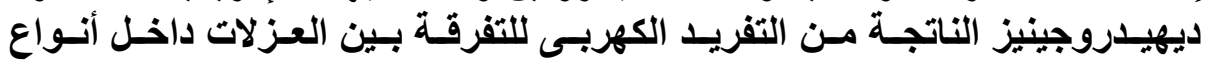

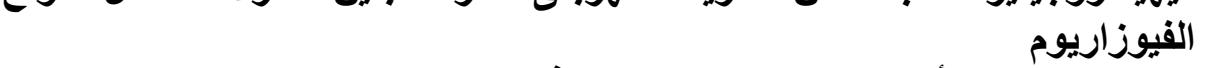

عبل الرحيم محمد أحمد السمواتى ، محمود توفيق محمود منصور ،معوض رجب عمر

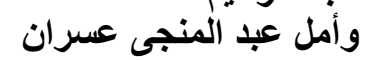
معها بحوث أمراض النباتات ، مركز البحوث الزراعية ، الجيزة ، مصر.

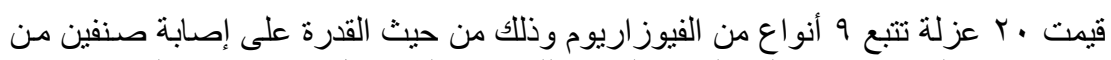

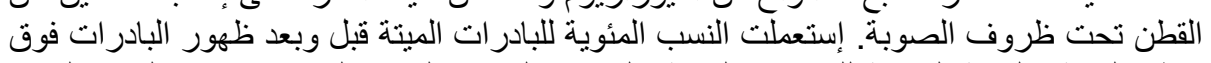

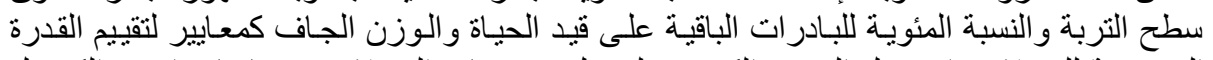

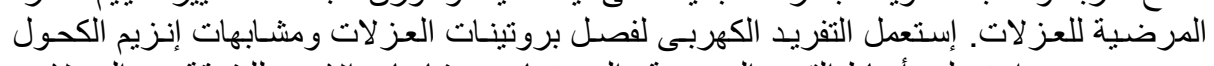

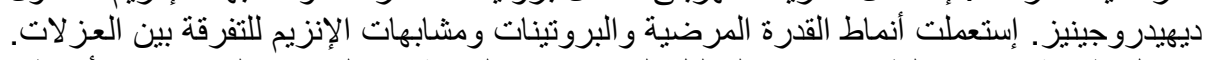

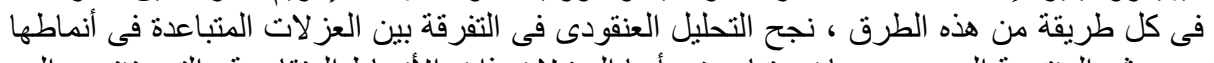

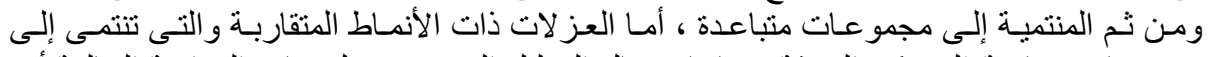

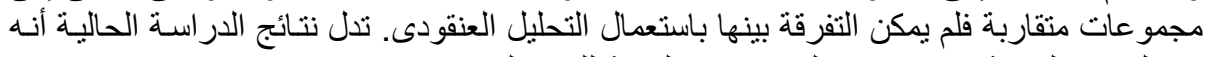

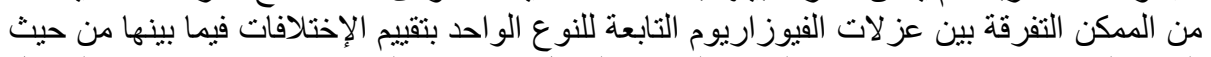

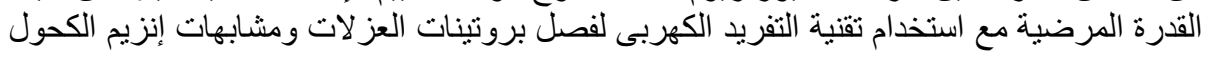

ديهيدروجينيز. 